\title{
Analisis mașlaḥạ̣ dalam millennium development goals
}

\author{
N. Oneng Nurul Bariyah, Siti Rohmah \\ Universitas Muhammadiyah Jakarta \\ Jl. KH. Ahmad Dablan Cireundeu Ciputat \\ E-mail:noer_fai@yaboo.co.id
}

The analysis of Mașlahah in the Millennium Development Goals . This research is a study Maṣlahah of the Millennium Development Goals (MDGs). The focus of this research is Maṣlahah of five MDG targets, namely: 1) Reduction of extreme poverty and hunger, Equity in education, 3) Supporting the equation of gender and empowerment of women, 4) Reduce child mortality, 5) Improve maternal health The method of research used qualitative analysis. The data sources of this study is literature, Because this type of research is library research. The results Showed that the millennium goals are maṣlahah values that have an influence on the maintenance of maqāid al-Shari'ah, namely: to maintain religion, mind, spirit, Ancestry, wealth, lineage. All of this indicates the existence of universal values of Islamic law as rahmatan lil'alamin and suitable for all times and places (salih likulli zamān wa makēan).

Analisis Maṣlaḥaḥ Dalam Millennium Development Goals. Penelitian ini merupakan kajian Maṣlaḥạ̣ dalam Tujuan Pembangunan Milenium ( MDGs). Fokus penelitian ini adalah Maṣlaḥạ̣ dari lima sasaran MDGs, yaitu: 1) Pengentasan kemiskinan dan kelaparan ekstrim; 2) Pemerataan pendidikan dasar; 3) Mendukung adanya persamaan jender dan pemberdayaan perempuan; 4) Mengurangi tingkat kematian anak; 5) Meningkatkan kesehatan ibu. Metode penelitian menggunakan analisis kualitatif. Hasil penelitian menunjukkan bahwa dalam tujuan milenium terdapat nilai-nilai Maṣlaḥạ yang memiliki pengaruh terhadap terpeliharanya Maqāsid al-sharìah yaitu: memelihara agama, akal, jiwa, keturunan, harta, nasab. Semua itu menunjukkan nilai-nilai universal syari'at Islam sebagai rahmatan lil'alamin yang sesuai untuk semua masa dan tempat (sălih likulli zamân wa makāan).

Keywords: Millennium development goals; Mașlahah; al-Shari'ah 
ljtihad, Jurnal Wacana Hukum Islam dan Kemanusiaan, Volume 13, No. 2, Desember 2013: 141-162

\section{Pendahuluan}

Relasi antara Islam sebagai agama dengan kehidupan masyarakat dan budaya sangat jelas dalam kajian sosiologi dan antropologi agama. Dalam perspektif ini diyakini, bahwa agama merupakan refresentasi dari sistem budaya (Bassam Tibi, 1990: 10). Islam selain bersifat transendental, juga harus bersifat immanent, dalam arti harus dapat memberi daya dan pengaruh pada transformasi sosial, budaya, politik, ekonomi yang positif dan konstruktif.

Akselerasi kemajuan teknologi dan perkembangan informasi yang begitu cepat harus diimbangi dengan interpretasi dan kajian yang aktual dan bertanggungjawab dari doktrin shari'at Islam yang bersumber dari al-Qur'an dan Sunnah. Sebagai sumber ajaran Islam, alQur'an dan Sunnah merupakan landasan dalam menyelesaikan berbagai segala persoalan kehidupan. Akan tetapi, hal itu memerlukan kecerdasan akal untuk menggali dan mengkontekstualisasikan secara tepat dengan situasi dan kondisi yang berubah. Upaya reaktualisasi ajaran Islam, menjadi niscaya karena secara doktrinal Islam bersifat universal dan rahmat bagi seluruh alam. Universalitas ajaran Islam tampak dalam hal etika dan moral yang berhubungan dengan masalah-masalah moral dan kemanusiaan.

Berbagai persoalan kemanusiaan yang muncul di abad modern saat ini menuntut manusia untuk mengambil langkah-langkah strategis guna memberikan solusi. Kemiskinan, kelaparan, tingginya kematian anak yang dilahirkan serta kematian ibu, dan berbagai persoalan lainnya sebagai sesuatu yang perlu diatasi bersama. Atas dasar itu para pemimpin dunia dari 147 kepala pemerintahan pada bulan September 2000 mendeklarasikan Millennium Development Goals 2015. Bagi umat Islam, pencapaian tujuan MDGs tidak bisa lepas dari nilai-nilai dasar ajaran Islam yang salih likulli zamān wa makān (sesuai dengan waktu dan tempat). Untuk itu, kajian nilai-nilai Maṣlaḥah dalam MDGs merupakan suatu kajian atas prinsipprinsip ajaran Islam yang universal.

\section{Tinjauan pustaka}

Istilah Mașlạ̣ạ̣ secara etimologis berasal dari kata șalusa yașusu șalusan atau șalusa yașlusu salạsan yang memiliki pengertian yang sama dengan kata al-khayr (kebajikan), al-naf'u (kemanfaatan $=$ mendapatkan kenyamanan) (Husain Hāamid Hasan, 1981:4), al-Husn (kebaikan) (Ibn Manẓūr, 1424 H/2003m:348; Ibn Zakariyyā, ttp: 303), dan al-sawwāa (kebenaran) lawan 
dari al-fasād. Dengan demikian arti mașlahah secara bahasa adalah sesuatu yang membawa kebaikan, kemanfaatan, serta jauh dari kerusakan dan kemafsadatan. Dari arti bahasa kita dapat mengambil pengertian bahwa mașlahab itu memelihara kebaikan, kenyamanan, keutuhan, kesentosaan dan menghindari terjadinya kerusakan, kesulitan, dan petaka, hal demikan dapat mencakup berbagai aspek.

Maṣlahah dan mafsadat dalam arti bahasa sebagai bentuk yang antonim, antara manfaat dan madharat (kesulitan), baik dan buruk sebagaimana dikemukakan oleh 'Izz al-Dîn bin 'Abd al-Salâm, t.t.: 4) dalam bukunya sebagai berikut:

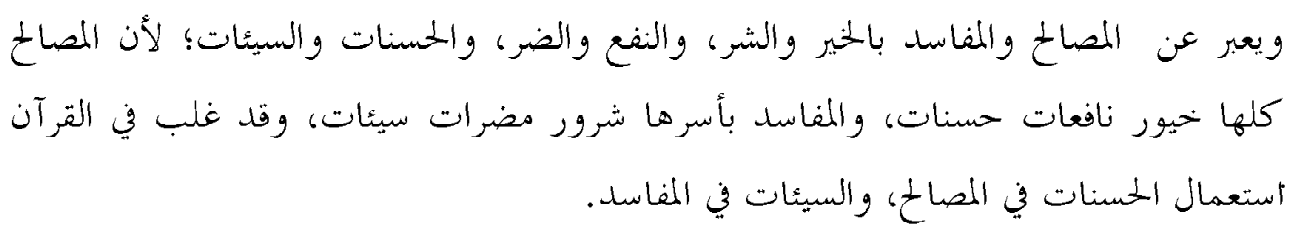

"Maṣlahah dan mafsadah diartikan sebagai (hal yang) baik dan buruk, bermanfaat dan merusak, serta kebaikan dan keburukan. Karena maṣlaḥah itu seluruhnya baik, bermanfaat dan bagus, sedangkan mafsadat itu semuanya buruk, merusak, dan jelek. Dalam alQur'an penggunaan (kata) al-Hasanät banyak digunakan untuk menunjukkan maṣlahạ dan (kata) sayyiät ( menunjukkan) mafsadat."

Sementara itu, para ahli hukum Islam (ulama ushul) mengartikan istilah maslạ̣ạ̣ dalam dua pengertian (Husain Hāamid Hasan , 1981: 5). Pertama: Maṣlặh berarti kenyamanan / kenikmatan atau cara untuk mendapatkan kenyamanan/kenikmatan. Upaya menghindari kesulitan (daf'u al-mafsadat) termasuk dalam pengertian tersebut. Dalam hal ini mereka membagi maslahah dan mafsadat yang bersifat nafsi, badani, duniawi, dan ukhrawi. Kedua; Maslạ̣ah merupakan salah satu dalil shara'. Dalam hal ini ada beberapa pendapat tentang mașlaḥah, antara lain Muḥammad bin Muḥammad al-Ghazali menyatakan bahwa maṣlaḥah intinya adalah upaya mendapatkan manfaat serta menghindari mafsadat (kerusakan). Menghindari kerusakan merupakan tujuan penciptaan manusia serta kebaikan manusia dalam mencapai tujuan mereka (al-Ghazali, 1413H: 174). Yang dimaksud dengan mașlạ̣ah adalah terpeliharanya tujuan shari'at. Tujuan shari'at ada lima yaitu: memelihara agama, jiwa, akal, keturunan, dan harta.(Mucmafa Zaid, 1974: 211). Demikian pula al-Khawarizmi berpendapat 
bahwa mạ̦laḥah itu adalah memelihara tujuan shara' melalui (upaya) menghindari berbagai kemafsadatan (al-Shaukāni, 1999M/1419H: 184). Sementara al-Shamibī (1997M/1417H: 17-23) membagi mașlaḥah menjadi tiga yaitu kemaslahatan yang primer (arüriyyāt), sekunder (bajjyāt) dan tersier (tahsiniyy $\bar{a}$ ). Semua kemaslahatan itu bertujuan untuk kemaslahatan manusia di dunia dan akhirat dan merupakan hal-hal yang harus terpelihara dalam pandangan semua agama (al-millah). (al-Shamibi (1997M/1417H:20). Pandangan al-Shamibï tersebut selaras dengan seluruh ajaran agama yang menyuruh penganutnya agar senantiasa menjaga keyakinan, tidka boleh membunuh, mencuri, berzina serta dilarang mabuk-mabukan.

\section{Maqāṣid al-shari'ah}

Istilah Maqāsid merupakan bentuk jamak dari kata maqsad yang asal katanya yaitu dari kata qasada (maksud) yang memiliki arti beragam yaitu bermaksud, niat, menghendaki, menuju kepada, mengikuti, memaksa, lurus (Munawwir,1984:1208). Dalam istilah fikih kata al-maqăsid (objectives of shari'ah, goals of shari'ab) berarti: makna, tujuan yang dikehendaki Shäri' dalam berbagai hukum shari'at. Selain itu, al-maqāsid juga bermakna tujuan shari'ah dan rahasiarahasianya yang ditetapkan oleh Shāri' (Pembuat shari'at) bagi setiap hukum shara' (Mucmafa Sânû, 2000:431). Secara etimologi, shari'ah berarti jalan yang dilalui air untuk diminum atau tangga tempat naik yang bertingkat-tingkat. Shari'ah juga diartikan siram al-mustaqim sebagaimana disebut dalam Al Qur'an surat al-Jăthiyah/45 ayat:18

Shari'ah dalam hukum shara' merupakan hukum taklif yang bersifat praktik sebagaimana disebut dalam al-Quran surat al-Maidah ayat 48. Shari'ah (law of Islam, Divine law) juga berarti kumpulan pokok-pokok ajaran, aqidah, dasar-dasar (agama), politik, kemasyarakatan, ekonomi, dan pidana yang ditetapkan oleh Allah untuk mengatur kehidupan individu dan masyarakat di muka bumi sesuai yang dikehendakiNya (Mușmafa Sanū, 2000:249). Dari pengertian tersebut dapat difahami bahwa shari'ah memiliki fungsi sebagai pengatur kehidupan manusia di muka bumi ini. Apabila manusia tidak mengikuti syari'ah, maka kehidupan akan kacau. Pembebanan (taklif) hukum syari’at memiliki maqāsid bagi makhluk terbagi tiga macam, yaitu: arüriyyāt, hạjiyyāt, dan taḅsiniyyāt (Mucmafa Sānū, 2000:17).

Istilah Millennium Development Goals disingkat MDGs merupakan kesepakatan bangsabangsa yang menjadi tujuan pembangunan global yang diupayakan untuk dicapai pada tahun 
2015 (http//www.un.org/milleniumgoals). MDGs meliputi : 1) Pengentasan kemiskinan dan kelaparan yang ekstrim 2) Pemerataan pendidikan dasar, 3) Mendukung adanya persaman jender dan pemberdayaan perempuan, 4) Mengurangi tingkat kematian anak, 5) Meningkatkan kesehatan ibu, 6) Perlawanan terhadap HIV/AIDS, malaria, dan penyakit lainnya, 7) Menjamin daya dukung lingkungan hidup, dan 8) Mengembangkan kemitraan global untuk pembangunan.

\section{Metodologi penelitian}

Fokus penelitian pada lima tujuan dari MDGs yaitu analisis masalah dalam pengentasan kemiskinan dan kelaparan, pendidikan dasar, persamaan jender dan pemberdayaan perempuan, pengurangan tingkat kematian anak dan peningkatan kesehatan ibu

Penelitian ini menggunakan metode kualitatif. Sumber data yang digunakan ada dua macam yaitu data primer dan sekunder. Data primer yang digunakan antara lain: al-Mustafa fî 'il al-Ușūl karya al-Ghazali, Mu’jam Musmalahật Ușūl al-Fiqh Arab-Inggris karya Quthb Muṣmafa Sānū, al-Muwāafaqāt karya al-Shāmibi, al-Maqāsid al-Ammah li al-Sharìat al-Islämiyyah karya Yùsuf Hāmid al-Ālim. Teknik pengumpulan data yang dilakukan yaitu penelusuran terhadap sumber data berupa pustaka baik berupa buku, surat kabar, media cetak maupun elektronik.

Analisa data pustaka menggunakan Content Analysis. Analisis dilakukan terhadap isi gagasan yang ada dalam tujuan pembangunan global atau Millennium Development Goals. Analisis dilakukan dengan melakukan interpretasi terhadap ayat-ayat al-Qur'an dan hadis dengan pendekatan konsep mașahạ. Dalam melakukan analisis dilakukan tahapan-tahapan, yaitu identifikasi data, klasifikasi, serta interpretasi. Interpretasi data dilakukan agar diperoleh pemahaman secara mendalam terhadap konsep tujuan pembangunan global dengan pendekatan maqăsid al-shari'ah.

\section{Hasil penelitian dan pembahasan}

Pengentasan kemiskinan dan kelaparan ekstrem (end poverty and hunger)

Secara etimologi kata "miskin" berasal dari bahasa Arab sakana yaskunu sukünan yang artinya lemah, rendah, tunduk. bentuk mashdarnya yaitu al-maskanah yang memiliki arti al- 
hâjat (orang yang membutuhkan) dan al-khü' (kepatuhan). Dalam pengertian istilah, kata miskin memiliki beberapa arti, yaitu (Ibn Sâlim Bazimul, t.t: 7): Kebutuhan manusia terhadap pihak lain, Fakir hati dan jiwa artinya ketidakrelaan (tidak qanäab), dan sedikit harta, dalam konteks tersebut ada dua macam, yaitu: 1) sedikit harta disertai adanya kemampuan ; 2) sedikit harta serta tidak memiliki kemampuan. Istilah miskin dalam konteks tertentu tidak selalu menunjukkan pada kondisi kekurangan harta bisa juga bermakna orang yang hatinya lapang, dan orang fakir adalah orang yang kikir hatinya.Hal itu disebut dalam sabda Nabi Muhammad saw. yang berbunyi:

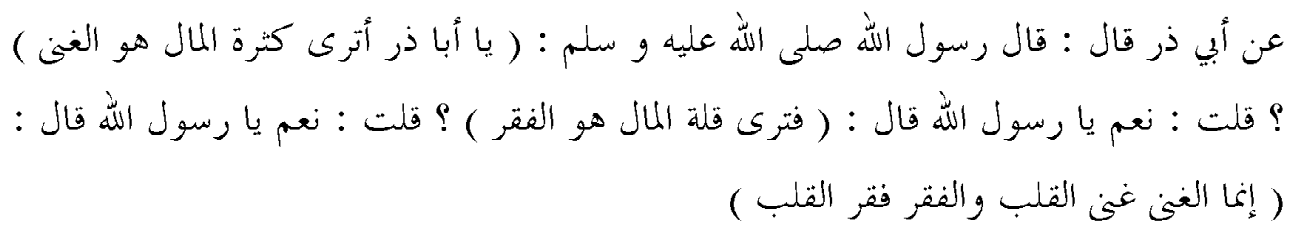

Artinya: Diriwayatkan dari Abi Dzar dia berkata: Rasulullah saw bersabda: "Wahai Abu Dzar apakah menurut pendapatmu bahwa orang kaya itu adalah orang yang banyak harta? Saya menjawab: "Benar ya Rasulullah." (Beliau) bersabda: Jadi, engkau berpendapat bahwa orang yang sedikit harta itu adalah orang fakir? Saya berkata:" Benar, ya Rasulullah." (Beliau) bersabda:" Sesungguhnya orang kaya itu adalah orang yang kaya jiwanya dan orang fakir adalah orang yang kikir jiwanya.” (Ibn Salim Bazimul, t.t :7)

Dalam keterangan hadis Nabi di atas, orang fakir bukanlah orang yang tidak berharta, melainkan orang yang kikir jiwanya. Adapun orang kaya bukan karena banyak hartanya melainkan besar jiwanya.

Dalam perspektif Islam, kemiskinan dan kelaparan merupakan sesuatu yang harus dihindari. Oleh karena itu, setiap muslim diperintahkan untuk membantu orang-orang miskin, bahkan membiarkan orang-orang miskin dalam kelaparan merupakan suatu bentuk perbuatan tercela, bahkan termasuk mendustakan agama (surat al-Mànūun/107:1-3). Jadi, upaya mengentaskan kemiskinan sebagai bagian dari ibadah termasuk dari hablun minannas (hubungan kecintaan antar sesama manusia). Pengentasan kemiskinan sebagai bagian dari realisasi memelihara agama (bif̧a al-din) baik bagi si miskin maupun bagi si pemberi. 


\section{Dampak kemiskinan dalam kehidupan}

Kemiskinan yang terjadi pada manusia dapat membawa dampak negatif terhadap kehidupan. Beberapa dampak negatif kemiskinan adalah sebagai berikut:

\section{Mengikis keteguhan beragama (akidah)}

Shari'at agama diwajibkan kepada umat manusia bertujuan memelihara keimanan /aqidah (حفظ الدين). Praktik ibadah tidak bisa lepas dari material atau benda (harta) yang harus dicari. Terkait masalah tersebut Rasulullah saw. menyatakan dalam sebuah hadisnya bahwa hampir saja kefakiran itu dapat membawa pada kekufuran. Hadis tersebut berbunyi sebagai berikut:

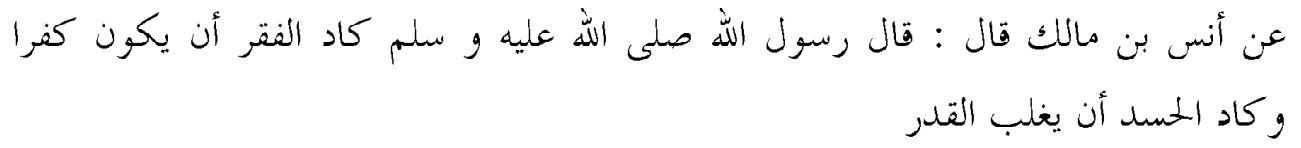

Artinya: Diriwayatkan dari Anas dia berkata: Rasulullah saw bersabda: Kefakiran itu hampir saja membawa kekufuran dan iri hati itu dapat mengalahkan takdir." (al-Bayhaqi, 1420 H, 267; al-Qadhai, 1986M/1407, 342

Keimanan seseorang dapat direalisasikan dalam bentuk perilaku yang baik. Perilaku yang salah dan tidak sesuai dengan ajaran Islam dinilai sebagai bentuk penyimpangan akidah. Oleh karena itu Nabi Muhammad saw. menetapkan kriteria atau sifat orang-orang beriman dengan profilnya yang baik serta selalu menjaga perilakunya.

Indikator kebaikan perilaku dapat terlihat secara lahir antara lain tidak melakukan pencurian, perzinaan, perampokan, dan lain-lain. Seorang muslim yang mencuri, berzina, dan perilaku lainnya yang buruk maka pada saat orang itu melakukan perbuatan tercela itu dia tidak disebut sebagai orang beriman. Demikian disebutkan dalam hadis yang berbunyi:

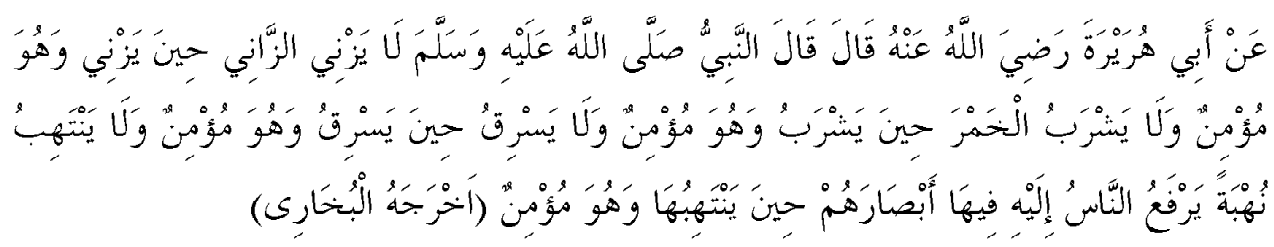

Artinya: Diriwayatkan dari Abi Hurairah bahwa Nabi saw., bersabda:’Tidaklah seorang pezina yang melakukan zina itu dalam keadaan beriman, dan tidak (pula) seorang peminum arak dia minum (arak) dalam keadaan beriman. Tidak (pula) seseorang yang mencuri 
ketika mencuri dalam keadaan beriman, "Dan tidaklah seseorang yang merampas barangbarang berharga yang dipandang oleh manusia, dalam keadaan tidak (sempurna) imannya". ( al-Bukhârî, 1422: 136)

Maksud hadis di atas bahwa semua perbuatan tercela seperti mencuri, merampok, korupsi, berzina, dan perbuatan buruk lainnya bukan karakter dan sifat orang yang beriman. Orang beriman adalah orang yang selalu berperilaku baik.

Kemiskinan harus dijauhi karena dapat mengakibatkan rusaknya keimanan seseorang. Nabi Muhammad saw. memberikan contoh agar selalu memohon kepada Allah SWT agar terhindar dari kemiskinan. Hal ini dapat dilihat dalam ungkapan beliau yang berbunyi:

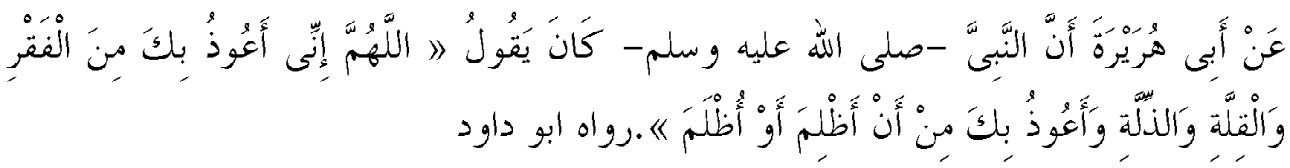

"Diriwayatkan dari Abu Hurairah bahwa Nabi saw. bersabda: "Ya Allah aku berlindung kepada-Mu dari kefakiran, kemelaratan, dan kehinaan, dan aku berlindung kepada-Mu dari menganiaya dan dianiaya (dizhalimi).” (Abū Dāwud, t.t.:566)

Dalam pandangan Nabi, kemiskinan yang sangat berbahaya yaitu miskin jiwa (Ibn Hibbān, 1992M/1414H: 460) sekalipun dia berkecukupan. Yang dimaksud miskin jiwa yaitu suatu kondisi kejiwaan seseorang yang tidak merasa cukup dan tidak mau bersyukur kepada Allah. Salah satu sifatnya yaitu tidak memiliki rasa iba dan peduli kepada saudaranya yang miskin. Dengan demikian kemiskinan dapat mengganggu bahkan mengikis keimanan pada gilirannya berpengaruh terhadap rusaknya harta, jiwa,dan kehormatan.

\section{Membahayakan perilaku dan moralitas}

Kemiskinan dapat berpengaruh terhadap perilaku dan moralitas masyarakat. Berbagai bentuk perilaku yang ditimbulkan karena kemiskinan antara lain: mengemis (meminta-minta), mencuri, melakukan perbuatan asusila, dan trafickking. Ajaran Islam mencela perilaku meminta-minta. Umat Islam diperintahkan mencari nafkah buat membekali kehidupannya. Budaya memintaminta merupakan perbuatan yang dicela oleh agama dan peminta-minta itu sebagai orang yang tidak memiliki harga diri. 
Ancaman bagi orang yang suka meminta-minta dapat dilihat dalam suatu keterangan dalam hadis Nabi Muhammad saw. yang berbunyi sebagai berikut:

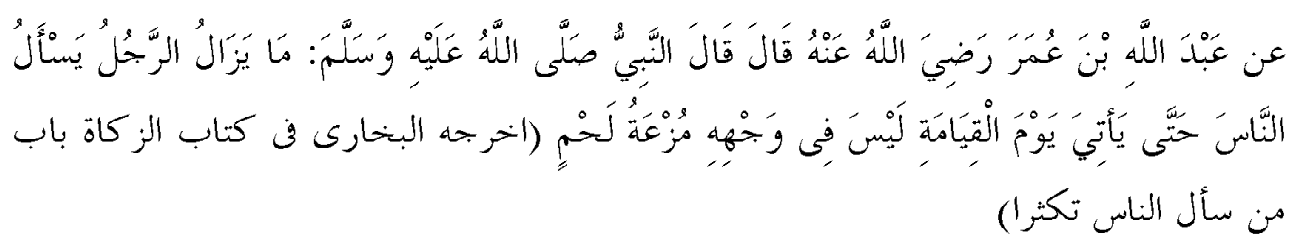

Artinya: Dari Abdullah bin Umar ra. ia berkata ; "Nabi saw. Bersabda: "Seseorang yang selalu meminta-minta kepada orang lain, akan datang pada hari kiamat dengan muka tanpa berbungkus dengan daging." (al-Bukhāri, 1422H: 123)

Hadis di atas menunjukkan bahwa meminta-minta merupakan perbuatan tercela yang harus dihindari. Manusia harus selalu berusaha untuk memenuhi kebutuhan hidupnya dengan melakukan aktifitas yang halal sesuai dengan kemampuannya. Umat harus dimotivasi agar mau berusaha mencari penghidupan tanpa menggantungkan diri kepada orang lain.

Untuk itu, Allah SWTT. menyuruh manusia agar mencari rezeki untuk memenuhi kebutuhan hidup di dunia (QS. surat al-Jumu'ah /62:10). Nabi Muhammad saw. pun menyuruh umatnya agar selalu berusaha dan bekerja dengan kemampuan yang dimiliki sebagaimana dalam sabdanya

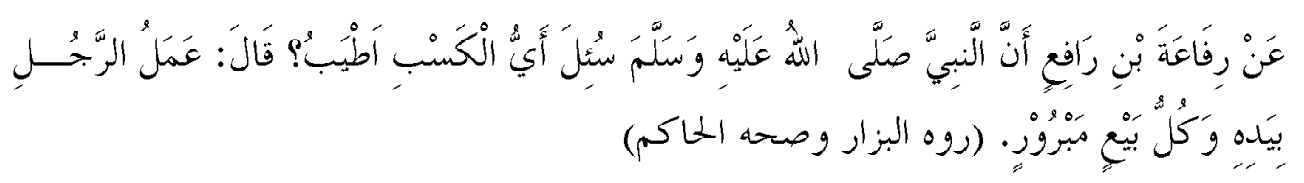

Artinya: Dari Rifa'at bin Rafi' (diriwayatkan) bahwa Nabi saw., (pernah) ditanya tentang apa pekerjaan yang paling baik? Nabi menjawab: (pekerjaan yang paling baik adalah) usaha seseorang yang diperoleh dari hasil tangannya sendiri dan setiap jual beli yang jujur. (HR. al-Bazar dan dbenarkan oleh Hakim) (al-'Asqalani, t.t.: 292)

Hadis di atas memberikan motivasi agar manusia berusaha mencari penghidupan sendiri sesuai dengan kemampuannya. Dengan mencari pernghidupan yang halal manusia telah mengikuti perintah shara' yaitu memelihara harta (hifzal-māl). 
ljtihad, Jurnal Wacana Hukum Islam dan Kemanusiaan, Volume 13, No. 2, Desember 2013: 141-162

\section{Bahaya kemiskinan terhadap perilaku dan moral}

Kemiskinan menjadi salah satu alasan melakukan tindakan kriminal oleh sebagian masyarakat.Memegang teguh etika dan moral merupakan cara masyarakat hidup aman, tenteram, dan damai. Namun, jika hal tersebut tidak ada, maka tindakan asusila pun menjadi pilihan yang tidak terelakan walaupun mereka menyatakan terpaksa melakukannya. Selain itu, pencurian dan perampokan yang dilakukan sekelompok orang bahkan sampai melakukan pembunuhan tampaknya seperti hal yang biasa, padahal yang demikian sungguh sangat bertentangan dengan etika dan moral.

\section{Kemiskinan menghambat kemajuan pendidikan dan peradaban manusia}

Pendidikan merupakan salah satu faktor pendukung terjadinya kemajuan peradaban manusia. Dengan pendidikan yang maju, manusia dapat melakukan inovasi dalam berbagai bidang baik kesehatan, ekonomi, dan yang lainnya karena kemajuan ilmu pengetahuan. Namun, semua itu sulit untuk dicapai manakala kemiskinan melanda manusia. Karena, kemiskinan dapat terjadi akibat sulitnya akses penduduk terhadap informasi. Penduduk di daerah pedalaman sebagai bagian yang rentan kemiskinan karena kesulitan akses baik kesehatan, pendidikan, maupun ekonomi. Keadaan tersebut dapat pula terjadi di perkotaan.

\section{Kemiskinan mengganggu ketenangan rumah tangga}

Salah satu indikator terwujudnya rumah tangga yang baik adalah terpenuhinya kebutuhan material. Karena, tanpa adanya materi seorang suami tidak mungkin dapat memenuhi kewajibannya memberi nafkah kepada anak dan isteri. Oleh karena itu, Nabi Muhammad saw. mengingatkan umatnya agar perkawinan itu dipersiapkan dengan matang, salah satunya dengan kesiapan materi. Nabi Muhammad saw. bersabda:

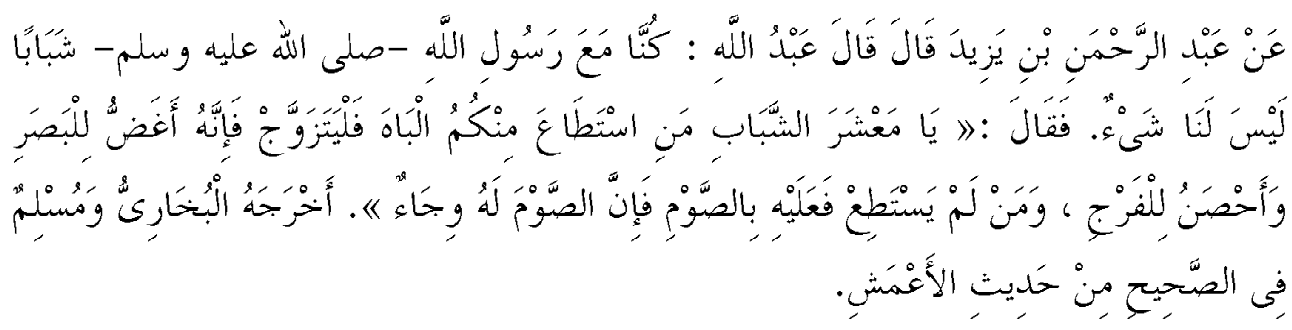


Diriwayatkan dari Abdurrahman dia berkata, Abdullah berkata: Kami berada bersama Rasulullah saat itu kami sebagai pemuda yang tidak memiliki apa pun. Maka, beliau bersabda: "Wahai para pemuda, siapa diantaramu yang telah mampu untuk kawin, maka kawinlah, karena perkawinan itu lebih memelihara penglihatan dan lebih menjaga kehormatan dari kerusakan seksual. Siapa yang belum mampu hendaklah puasa, karena puasa itu baginya dapat mengekang syahwat." (Ditakhrij oleh al-Bukhari dan Muslim dalam kitab șahị melalui riwayat al-A’mash) (al-Bayhaqi,1344H:296)

Rasulullah saw. memberikan petunjuk demikian karena perkawinan bukanlah waktu sesaat dan bukan perkara main-main. Kebutuhan dalam kehidupan rumah tangga akan semakin banyak dengan lahirnya keturunan. Maka, apabila tidak ada kemampuan untuk memenuhi kebutuhan material, kemiskinan akan terjadi.

Akibat kemiskinan dapat pula mendorong suami isteri melakukan perbuatan tercela. Salah satunya seperti membunuh anak baik masih dalam kandungan atau sesudah lahir. Pembunuhan tersebut dilakukan karena mereka ketakutan akan kesulitan dalam memenuhi kebutuhan biaya hidup. Dalam hal ini, Allah SWT mengingatkan manusia agar senantiasa memelihara keturunannnya dan dilarang melakukan pembunuhan (al-Isrâ (17) :31) Membunuh anak seebagai perbuatan tercela yang harus dihindari. Selain itu, memelihara keturunan (bif al-nasl) sebagai bagian dari tujuan shari'at. Setiap manusia harus menjaga keutuhan berumah tangga, karena keluarga sebagai tonggak sebuah masyarakat. Apabila setiap keluarga tenteram, maka akan terwujud masyarakat yang tenteram.

\section{Pengaruh kemiskinan terhadap regenerasi}

Kemiskinan memiliki pengaruh terhadap regenerasi. Dalam masalah ini, generasi yang terlahir sangat tergantung pada kondisi orang tua baik tingkat pendidikan maupun ekonomi. Maka, apabila kemiskinan banyak melanda kehidupan manusia, maka generasi yang akan terlahir adalah generasi produk kemiskinan yang sangat dekat dengan kebodohan dan kekurangan gizi sehingga kemiskinan akan berkelanjutan apabila tidak diatasi.

\section{Pengaruh kemiskinan terhadap kehidupan bermasyarakat}

Masalah-masalah kehidupan sosial seperti tawuran antar warga, rebutan lahan, pembunuhan, dan masalah lainnya yang ada pada masyarakat sangat erat kaitannya dengan 
masalah kemiskinan dan ketidakadilan. Akibatnya muncul berbagai kerawanan sosial dan kehidupan masyarakat menjadi tidak terkendali.

\section{Pengaruh Kemiskinan Terhadap Peradaban}

Kemajuan peradaban manusia sangat dipengaruhi oleh pendidikan dan ekonomi. Apabila pendidikan dan ekonomi terbelakang, maka kemiskinan akan terjadi. Karena, faktor-faktor terjadinya kemiskinan menurut Ginanjar Kartasasmita (1996: 240-241) sekurang-kurangnya ada 4, yaitu: Rendahnya taraf pendidikan, rendahnya derajat kesehatan, terbatasnya lapangan kerja. dan kondisi keterisolasian. Masyarakat yang terisolasi akan kesulitan karena tidak memiliki akses pendidikan, kesehatan, lapangan kerja sehingga kesulitan untuk melakukan gerak langkah kemajuan. Oleh karena itu, untuk mengatasi kemiskinan yang demikian pembangunan harus merata ke seluruh wilayah.

\section{Pendidikan dasar (universal education)}

\section{Pendidikan bagi kehidupan manusia}

Pendidikan merupakan sesuatu yang sangat penting bagi manusia sehingga perintah pertama dalam firman Allah kepada Nabi Muhammad adalah membaca (Iqra). Perintah membaca menunjukkan pentingnya pendidikan dan menjadi dasar untuk kemajuan peradaban manusia yang terlahir ke muka bumi tanpa ilmu pengetahuan apa pun (QS. al-Nahl/16: 78). Padahal dia mengemban amanah untuk mengabdi kepada Tuhan serta membawa kemakmuran di muka bumi. Tanpa ilmu pengetahuan, manusia tidak dapat mengemban semua tugas yang diberikan Tuhan kepadanya. Orang yang berilmu memiliki derajat yang lebih tinggi di sisi Allah daripada orang yang tidak berilmu (QS. al-Mujādalah/58:11). Karena dengan ilmu pengetahuan yang dimiliki, seseorang dapat melakukan berbagai aktifitas kebaikan.

Ilmu pengetahuan sebagai bekal hidup manusia memiliki kegunaan yang sangat urgen bagi manusia terkait pemeliharaan tujuan syari'at, yaitu:

\section{Memperkuat keimanan}

Keimanan merupakan pondasi bagi setiap muslim. Keimanan meliputi keyakinan hati, perkataan, serta tindakan atau perilaku. Realisasi iman dapat terwujud manakala seorang 
muslim memiliki ilmu pengetahuan. Ilmu pengetahuan yang dimaksud dalam merealisasikan keimanan adalah pengamalan terhadap apa yang kita ketahui berupa amal saleh.

\section{Memelihara keturunan.}

Perbuatan baik dan buruk dapat diketahui dengan adanya ilmu pengetahuan termasuk melakukan pergaulan bebas yang dapat membawa pada perzinaan. Perzinaan sebagai perbuatan tercela yang harus dijauhi (QS. al-Isrā/17 : 32) karena telah menimbulkan efek negatif. Dengan ilmu yang dimiliki seseorang menahan diri dari perbuatan tidak terpuji, kare na ilmu adalah amal.

\section{Memelihara harta}

Harta sebagai penopang kehidupan manusia harus diperoleh dengan cara halal (QS. alBaqarah/02: 168). Untuk memperoleh harta yang halal tentu harus ada keterampilan sebagai buah dari ilmu pengetahuan. Adanya ilmu pengetahuan akan memberikan bekal bagi seseorang mencari penghidupan yang lebih layak dibandingkan dengan orang yang tidak berilmu. Demikian merupakan salah satu keutamaan orang yang berilmu atas orang-orang yang tidak berilmu (QS. al-Mujādalah/58:11). Orang yang berilmu tentu akan diberikan jabatan yang lebih tinggi daripada orang yang tidak berilmu.

\section{Terpeliharanya akal dan fikiran}

Dalam rangka memelihara akal fikiran, manusia dilarang untuk mengkonsumsi makanan atau minuman memabukkan (QS. al-Mäidah/05:90). Karena mengkonsumsi sesuatu yang memabukkan dapat menghilangkan akal pikiran sehingga tidak mampu berfikir secara baik dan tidak dapat mengatasi persoalan hidup. Akal fikiran yang terganggu tidak hanya merusak fisik dan mental seseorang tetapi mengakibatkan pengaruh yang buruk bagi semua, baik diri, keluarga, masyarakat dan bangsa serta masa depan kehidupan mansuia. Ilmu pengetahun dapat mempertajam pemikiran seseorang. Dengan ketajaman akal fikiran manusia dapat melahirkan inovasi dan berbagai hal baru sehingga bermanfaat bagi kehidupan dan kemajuan bagi peradaban dunia. Di sinilah letak pentingnya pendidikan sebagai sarana memelihara akal fikiran (hif žal-aqh) dan terpeliharanya eksistensi manusia. 


\section{Terpeliharanya jiwa}

Jiwa manusia merupakan amanah dari Allah SWT yang harus dipelihara. Manusia dilarang membunuh. Seseorang yang telah membunuh satu orang manusia sama dengan melenyapkan banyak orang, sedangkan manusia yang menghidupkan satu orang, maka dia telah menghidupakan banyak orang (Ibn Kathîr, 1999M/1420H: 9). Orang yang membunuh jiwa seseorang telah menghapus masa depan banyak orang, sedangkan orang yang memelihara kehidupan, dia telah memberi peluang kehidupan banyak orang.

\section{Pengarub buruk jika tidak ada ilmu pengetabuan}

Ilmu pengetahuan merupakan suatu kemampuan yang dimiliki manusia dalam menghadapi kehidupan. Selain itu, ilmu pengetahuan merupakan alat untuk membentengi seseorang melakukan perbuatan-perbuatan terlarang. Berikut ini beberapa akibat yang akan terjadi jika ilmu pengetahuan lenyap, antara lain:

1. Kebodohan

Kebodohan/ketidaktahuan merupakan akibat utama hilangnya ilmu pengetahuan. Akibat tidak memiliki ilmu menimbulkan kesulitan dalam memecahkan berbagai persoalan. Kehidupan akan terasa gelap karena tiada ilmu. Oleh karena itu, ilmu sebagai penerang kehidupan seseorang.

2. Kebinasaan

Kebinasaan dan kerusakan akan terjadi manakala tiada ditemukan lagi orang yang memiliki ilmu pengetahuan. Hilangnya seseorang yang ahli dalam bidang ilmu tertentu maka akan menjadikan kesulitan manakala ada persoalan.

3. Maraknya prostisusi

Perbuatan tercela sebagai akibat lenyapnya ilmu pengetahuan yaitu maraknya prostisusi. Hal ini akibat tidak adanya pengetahuan manusia tentang efek negatif dari perilaku tersebut. Nalar manusia telah kalah oleh nafsu yang membawa manusia pada kebinasaan dan kerusakan moral.

4. Maraknya pembunuhan

Kehidupan manusia yang diliputi nafsu amarah telah membawa mereka pada kondisi tidak nbormal sehingga melakukan pembunuhan. Dengan berbagai motif pembunuh- 
an sebagai tindakan sangat biadab, baik menggunakan senjata canggih maupun senjata sederhana. Seseorang yang telah melakukan pembunuhan telah melanggar hak asasi seseorang yaitu hak hidup. Oleh karena itu, dalam hukum Islam, seseorang yang sengaja melakukan tindakan pembunuhan sesuai dengan ketentuan syara' maka dikenai hukum bunuh sebagai balasan yang sesuai dengan tindakannya.

5. Maraknya konsumsi obat dan minuman terlarang

Obat-obatan terlarang saat ini kian marak dikonsumsi serta diproduksi oleh kelompok yang tidak bertanggung jawab. Bisnis obat-obatan terlarang menggiurkan dan menarik sebagian kelompok manusia sehingga berusaha untuk menjadikannya sebagai lahan bisnis. Mereka tidak memikirkan efek negatif dari konsumsi obat-obatan tersebut yang mengakibatkan hilangnya akal pikiran dan masa depan manusia. Secara tidak langsung, obat-obatan terlarang itu sebagai sesuatu yang menghilangkan generasi manusia.

Persaman jender dan pemberdayaan perempuan (gender equality)

\section{Prinsip-prinsip Dasar Persamaan hak laki-laki dan Perempuan}

Prinsip-prinsip dasar persamaan antara semua makhluk dalam ajaran Islam didasarkan pada beberapa hal sebagai berikut (Ibn 'Abd al-Muhsin al-Turki, 1419 H:27-35):

1. Ajaran agama menempatkan kedudukan sama antara laki-laki dan perempuan Eksistensi agama bagi setiap manusia merupakan sesuatu yang penting dan bagian dari kebutuhan yang bersifat aruriyat. Aturan shari'at ditetapkan bagi kemaslahatan manusia yang diperintahkan untuk menjaga segala perilakunya dari perbuatan tercela, agar perbuatannya selalu bermanfaat bagi diri dan orang lain.

2. Hukum shari'at yang ditetapkan Allah sebagaimana disebut dalam al-Qur'an berhubungan dengan kedudukan dan martabat manusia sebagai makhluk yang dkarunia kemuliaan. Hal ini tertuang dalam al-Qur'an surat al-Isrāa ayat 70 .

3. Manusia memiliki derajat yang sama dan berasal dari keturnan yang sama yaitu dari Nabi Adam yang disebut dengan istilah Bani Adam (Keturunan Adam) sehingga perbedaan rupa dan warna kulit tidak menjadi persoalan. Manusia hidup harus bekerjasama dilarang membunuh saudaranya. Setiap manusia hidup sepenanggungan dengan saudaranya 
sehingga memiliki kewajiban untuk menaggung saudaranya sebagaimana dimuat dalam surat al-Ma'ârij/70 ayat 24-25.

Kemuliaan manusia terletak pada tingkat ketakwaannya (QS. al-Hujurāt: 13) yaitu orang yang memiliki rasa takut kepada Allah dengan selalu melakukan amal saleh. Amal saleh yaitu pebuatan-perbuatan yang disukai Allah dan memberikan manfaat bagi kheidupan manusia yang aman, damai, dan tenteram.

4. Kemuliaan manusia dalam pandangan Islam terletak pada keutuhan akidah dan kemuliaan perilakunya. Prinisp dasar kemuliaan manusia terletak pada essensinya yaitu:

a. Manusia sebagai makhluk paling mulia. Allah telah memberikan ilmu pengetahuan kepada manusia (QS. al-Baqarah/02: 31) yang tidak dimiliki mahkhluk lain. Manusia diciptakan oleh Allah dalam bentuk yang paling baik (QS. al-Tin/95: 04). Namun, dalam satu segi manusia juga merupakan makhluk yang lemah (QS. al-Nisāa4:08) dalam hal penciptaannya yang berkembang menurut proses pertumbuhan dan perkembangan fisiknya menuju kesempurnaan.

b. Manusia memiliki keturunan sama dari Nabi Adam tidak pantas untuk merasa dirinya lebih tinggi dan mulia dari pada yang lain.

Dengan melihat hakikat manusia sebagai ciptaan Tuhan, maka seluruh manusia memiliki persamaan sehingga tidak patut bagi sebuah bangsa merasa lebih tinggi daripada yang lainnya. Semua manusia berasal dari keturunan yang sama yaitu Adam dan Hawa.

\section{Mengurangi tingkat kematian anak}

Pemberian makanan bergizi bagi bayi merupakan salah satu langkah dalam upaya memelihara keturunan sebagai generasi mendatang. Dalam perspektif ajaran Islam, langkah tersebut merupakan bagian dari pelaksanaan shari'at sebagai upaya menjaga kemaslahatan yang termasuk kategori al-mașālị̣ taḥsiniyyāt (embellishments/tersier), yaitu maṣlạ̣ạ yang keberadaannya untuk menyempurnakan pelaksanaan hukum shara'.

Upaya lain yang harus ditempuh dalam memelihara kehidupan bayi yaitu menjaga kesehatannya dengan memberikan imunisasi. Setiap insan yang telah menikah sangat mendambakan keturunan (anak). Apabila dihubungkan dengan kemaslahatan, keberadaan anak memberi maslahah duniawiyah dan ukhrawiyah. Terkait maqâcid al-Shari'ah seorang 
anak memiliki essensi bagi orang tua yang dapat berpengaruh terhadap pemeliharaan beberapa tujuan, yaitu:

\section{Memelihara Agama (حفظ اللدين)}

Anak merupakan amanah dari Allah SWT kepada pasangan suami isteri untuk dipelihara dan dididik. Anak terlahir dalam keadaan fitrah suci yaitu bertauhid, sehingga orang tua harus memelihara dan mendidiknya agar tetap pada kesuciannya. Usaha orang tua mendidik anak dengan baik akan dirasakan buahnya oleh orang tua itu sendiri ketika masih berada di dunia dan bahkan setelah wafat. Nabi Muhammad saw. bersabda: (al-Nawawi, t.t.: 478)

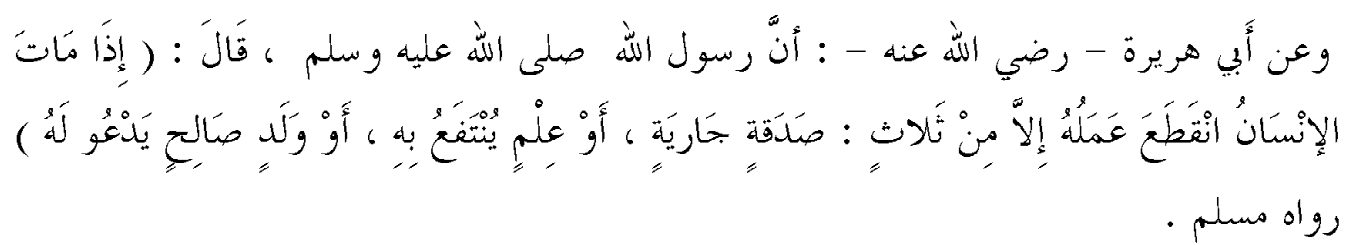

"Diriwayatkan dari Abu Hurairah ra. Bahwa Rasulullah saw, bersabda: "Jika seorang manusia meninggal dunia, maka terputus amalnya kecuali tiga yaitu: shadaqah jariyah, ilmu yang bermnafaat, dan anak saleh yang mendo'akannya." (HR Muslim)

Berdasarkan hadis di atas, maka seseorang yang berhasil mendidik anak akan mendapatkan balasan kebaikan baik ketika masih hidup maupun setelah meninggal dunia. Di sinilah letaknya hubungan anak dengan pemeliharaan keimanan orang tua, tidak melaksanakan amanah dengan baik berarti merusak akidah dan keyakinan.

\section{Memelihara regenerasi}

Anak merupakan indikator adanya keberlanjutan sebuah generasi. Dengan terpeliharanya anak dari ancaman kematian, maka sebuah keluarga akan tetap eksis. Sebagai penerus, anak akan melanjutkan langkah orang tua yang telah dirintisnya.

Memelihara kehidupan anak dari ancaman kematian sesungguhnya sebagai sebuah upaya besar dalam rangka menjaga keberlanjutan kehidupan manusia di dunia ini. Jika anak terancam dengan terkena berbagai penyakit sejak lahir atau bahkan sejak kandungan, maka kehancuran, menghantui kehidupan manusia. 
ljtihad, Jurnal Wacana Hukum Islam dan Kemanusiaan, Volume 13, No. 2, Desember 2013: 141-162

\section{Memelibara barta}

Anak sebagai generais penerus orang tua akan mendapatkan harta kekayaan sebagai warisan dari orang tuanya (QS. al-Nisā/04: 7). Kewarisan sebagai salah satu cara perolehan harta yang halal tanpa adanya transaksi. Memelihara harta sebagai salah satu dari Maqạsid al-Sharïah dimana manusia dilarang memperoleh harta dengan cara yang batil. Memperoleh warisan merupakan satu cara memperoleh harta yang halal sesuai petunjuk Alquran

\section{Anak sebagai sumber kebahagiaan}

Anak menjadi dambaan setiap orang yang telah berkeluarga dan menjadi permata hati (QS.alFurqān/25: 74) serta pelipur lara. Anak akan menjadi penghibur saat keluarga berkumpul dan melepaskan lelah setelah bekerja. Keceriaan anak memberikan kebahagiaan tersendiri bagi keluarga khususnya orang tua. Sebaliknya, apabila anak sakit, seluruh keluarga merasa resah dan gelisah. Seorang ibu dan bapak akan terganggu tidurnya karena anknya kesakitan.

Disisi lain anak sebagai ujian dan cobaan (QS. al-Anfāl/28). Manusia diuji oleh Allah apakah mau bersyukur atau tidak, apakah adanya anak dapat mendekatkan diri atau menjauhkannya dari Allah dengan menunaikan kewajiban mendidik dan memeliharanya. Aturan shari'at yang bertujuan untuk memelihara anak yaitu: (Ra'fat Farîd Suwaylam, 2004M/ 1425H: 67-71)

Shari'at memelihara ibu hamil baik fisik maupun psikis.

Shari'at Islam memberikan kemudahan dalam pelaksanaan shari'at yaitu kebolehan untuk tidak berpuasa bagi ibu hamil dan perempuan yang sedang menyusui anak jika berakibat buruk terhadap dirinya serta janin yang sedang dikandung. Nabi Muhammad saw. bersabda: (al-Nasâî, 1420H: 491)

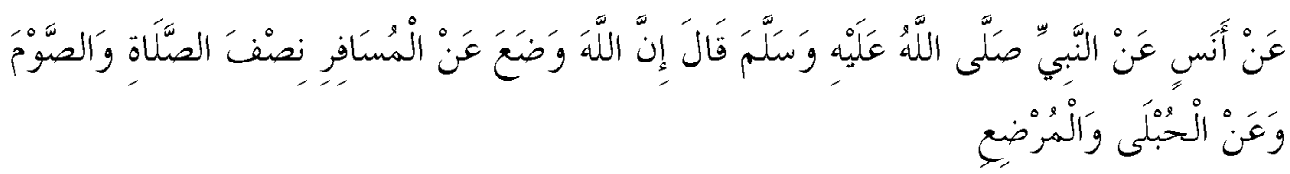

"Diriwayatkan dari Anas yang dia terima dari Nabi saw. beliau bersabda: sesungguhnya Allah memberikan keringanan shalat separuhnya (dari kewajiban saat hadir) bagi orang yang bepergian dan puasa orang-orang hamil dan menyusui." 
Hadis di atas memberikan petunjuk perhatian yang besar dari Shāri' (Tuhan YME) bagi umatNya agar mendapatkan kemudahan. Selain kemudahan di baliknya terdapat hikmah yaitu memelihara kesehatan mereka. Secara lahiriah, kemudahan itu berguna bagi ibu hamil agar memiliki kekuatan fisik yang baik sehingga dapat melahirkan anak dengan mudah.

\section{Meningkatkan kesehatan ibu (Maternal Healtb)}

Kematian ibu melahirkan sangat berpengaruh terhadap keadaan bayi yang dilahirkan jika bayinya lahir. Beberapa pengaruh akibat ibu meninggal saat melahirkan bagi bayi antara lain:

\section{Terganggunya penyusuan bayi}

Seorang bayi yang baru lahir membutuhkan air susu ibu, sehingga ibu dianjurkan untuk menyusui bayinya sampai dua tahun (QS. al-Baqarah/02: 233). Kemudian apabila penyusuan anak itu diberikan kepada orang lain (bukan si ibu) hendaknya mereka diberi upah. Firman Allah yang berbunyi:

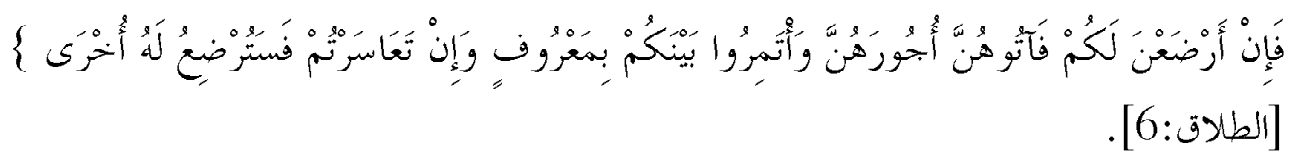

“..... kemudian jika mereka menyusukan (anak-anak)mu untukmu maka berikanlah kepada mereka upahnya, dan musyawarahkanlah di antara kamu (segala sesuatu) dengan baik; dan jika kamu menemui kesulitan maka perempuan lain boleh menyusukan (anak itu) untuknya.

Petunjuk tentang pemberian ASI bagi bayi sebagai bentuk kasih sayang Allah kepada umat manusia karena dalam penyusuan itu banyak manfaat bagi kesehatan bayi dan si ibu. Menurut Imam al-Razy dalam tafsir al-Kabir menyatakan bahwa menyusui dengan ASI lebih Maṣaḥah bagi bayi daripada diberi asupan susu lainnya (Husain Hamid Hasan, 1970: 119). Asupan ASI merupakan bagian dari al-mașälị̣ Tạ̣siniyyat (embellishments/tersier) untuk menjaga keselamatan jiwa .

Penjelasan dalam Al-Qur'an surat al-Baqarah ayat 233 tentang lama menyusui dianjurkan dua tahun merupakan petunjuk yang besar manfaatnya bagi manusia. Pengaruh positif bagi sang ibu, antara lain mengurangi resiko ibu terkena penyakit jantung, mengurangi resiko 
terkena kanker rahim dan payudara, membakar kalori pada tubuh ibu, menghemat pengeluaran, dan menumbuhkan ikatan yang kuat antara ibu dan anak. Selain itu menyusui anak menunda kembalinya siklus menstruasi pada ibu yang baru melahirkan.

\section{Berpengaruh pada kejiwaan}

Memberikan ASI pada bayi bagian dari usaha menghindari kemafsadatan (al-Syaukāni, 1999M/1419H: 184). Tujuan dari pemberian ASI pada dasarnya juga merupakan cara untuk menjaga Maqāsid al-shari'ah (menjaga agama, jiwa, akal, harta, dan keturunan) baik secara langsung maupun tidak langsung dan termasuk dalam kategori maṣlaḥạ̣ taḥsininyyah.

\section{Berpengaruh pada kesejahteraan}

Apabila seorang anak ditinggal ibu, maka si bapak akan mencari isteri penggantinya. Apabila si isteri baru kurang perhatian pada anak, maka hal ini akan mengakibatkan anak hidup dalam kondisi kurang sejahtera. Indikator kesejahteraan bukan hanya bersifat material tetapi juga kebahagiaan batiniyah.

Berdasarkan uraian di atas, tujuan pembangunan milenium selaran dengan nilai ajaran Islam yang telah lama disampaikan Allah dalam firman-Nya sera dalam sunnah Rasul-Nya dan memiliki manfaat sangat besar bagi kehidupan manusia.

\section{Penutup}

Tujuan pembangunan global (MDGs) berupa Pengentasan kemiskinan dan kelaparan yang ekstrim, pemerataan pendidikan dasar, persaman jender dan pemberdayaan perempuan, mengurangi tingkat kematian anak, dan peningkatkan kesehatan ibu memiliki keselarasan dengan tujuan shari'at Islam. Semua itu memiliki kemaslahatan yang berguna bagi kehidupan seluruh umat manusia di dunia ini. Upaya-upaya tercapainya semua tujuan pembangunan global seiring dan sejalan dengan ajaran agama Islam dan menjadi bagian dari jihad kemanusiaan. 


\section{Daftar pustaka}

Abu Dawud Sulaimān bin al-Asy'ats al-Sajistani, Sunan A $\bar{i} i$ Dāwnd Juz I. Bayrūt: Dār alKitāb al-'Arabiy, t.t.

al-'Asqalāni, Ibnu Hajar. Butugh al-Marâm min Adillat al-Abkāam, Juz I

al-Baihaqi, Abu Bakr Ahmad bin al-Husein bin 'Ali. al-Sunan al-Kubrā wa Dzailibi al-Jawhar alNaqi Juz IV.

al-Bayhaqi, Abu Bakr Ahmad bin al-Husayn. Sya'b al-Imān Juz V. Bayrūt: Dār al-Kutub al'ilmiyyah, 1420 H.Cet I

al-Ghazali, Abā Hamid Muhammad bin Muhammad. al-Mustasfā min Tlm al-Uṣūl Jilid I Tahqiq Hamzah bin Zuhair Hāfizh. Beirut: Dâr al-Fikr, 1413H

Ḥasan, Husain Hāmid. Na'ariyyat al-Mașlaḥạ̣ fi al-Fiqh al-Islämi. Mesir: Maktabah al-Mutanabi, 1981

Ibn Katsir, Abu al-Fida Ismail bin 'Umar. Tafsir al-Qur'-̄an al-'A “̈im Juz V. Ttp: Dār layyibah, 1420H/1999M

ibn Manzūr, Jamāl al-Dīn Muhammadin Mukarram. Lisāan al-`Arab Juz II. Riyāa Dār al'Alam al-Kutub, 1424 H/2003M

ibn Sâlim Bazimul, Muhammad 'Umar. Aḅkam al-Faqr wa al-Miskin. Ttp: Ttp

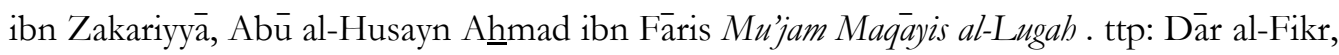
t.t.

ibn 'Abd al-Salām, Izz al-Dīn 'Abd al-'Aziz. Qawa'id al-Ahkēm f̄i Mashālih al-Anām Juz I Beirut: Dār al-Ma’āirif, t.t.. tahqqiq Mahmūd bin al-Talāmid al-Syanqìthi

Kartasasmita, Ginanjar Pembangunan Untuk Rakyat Memadukan Pertumbuhan dan Pemerataan. Jakarta: PT CIDESINDO, 1996

al-Nasai, Abu 'Abd al-Rahman Ahmad bin Syu'aib. Sunan al-Nasai bisyarh al-Suyuthi wa Hasyiyah al-Sanadiy Juz IV. Bayrūt: Dār al-Ma'rifat, 1420H. Cet V

al-Qusyairi, Muslim bin Hajjaj bin Muslim. Shahīh Muslim, Juz IV

Sânû, Quthb Mushthafa. Mu'jam Mushthalahāt Ushūl al-Fiqh Arab Inggris. Beirut: Dār al-Fikr, 1420H. Cet I

al-Sulami, Muhamamd bin 'Isā Abū Isāa al-Turmudzi. al-Jämi' al-Shabīh Sunan al-Turmudž $\bar{i}$ Juz IV. Bayrūut: Dār Ihyā al-Turāts al-'Arabī, t.t.

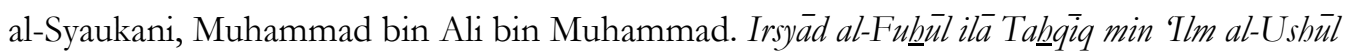
Juz II.Beirut: Dār al-Kutub al-A'Arabi, 1999M/1419H., Cet I

al-Syātibì, Ibrāhīm bin Mūsā bin Muhammad al-Lakhmi al-Gharnāthy (w.790H), Al-

Muwafaqāt. Beirut: Dār Ibn 'Affān.1417H/1997M. Jilid II 
ljtihad, Jurnal Wacana Hukum Islam dan Kemanusiaan, Volume 13, No. 2, Desember 2013: 141-162

Sugiyono, Metode Penelitian Pendidikan (Penelitian Kuantitatif, Kualitatif dan R $\approx D)$. Bandung: ALFABETA, 2009. Cet VIII

al-Turki, Abdullāh bin 'Abd al-Muhsin, Huqq al-Insān fi al-Isläm. Saudi Arabia: Kementerian Urusan Agama Islam, Wakaf, dan Dakwah Kerajaan Aausi Arabia, 1419 H. Cet I

Zaid, Musthafa. al-Maslahạ f̧ fi al-Tasyri al-Islami wa Najm al-Dïn al-Thui. Ttp: Dār al-Fikr al'Arabi, 1974

http://en.wikipedia.org/wiki/Millennium Development Goals\#Background, 20 April $2012 \mathrm{pkl} ; 14.35 \mathrm{WIB}$.

http://www.un.org/milleniumgoals.

BPS, Susenas 2010; CIT : Peta Jalan Pencapaian Tujuan Pembangunan Millenium di Indonesia. 